\title{
特集 核一マントルの相互作用と共進化に関する研究の進展
}

\section{第一原理計算による地球下部マントル鉱物の 格子熱伝導率の研究}

\author{
Study of Lattice Thermal Conductivity of Earth's Lower Mantle Minerals from \\ First-Principles Calculations
}

\section{出倉 春彦}

Haruhiko DEKURA

\begin{abstract}
In this article, recent progress on our first-principles calculations of lattice thermal conductivities of lower mantle minerals is reviewed. Effective thermal conductivity at the deepest mantle is modeled based on the compositional average. Heat flux from the core to mantle is then quantitatively estimated.
\end{abstract}

[first-principles calculation, anharmonic lattice dynamics, lattice thermal conductivity, lower mantle]

\section{1. はじめに}

地球の中心は 360 万気圧 $(\mathrm{GPa}) \cdot 5,000$ 度超の極 限環境であり, 中心から地表までの距離 $6,400 \mathrm{~km}$ に抢いて熱流束を生久出している。この結果, 地表 面に抢ける全熱流量は約 46 兆ワット（TW）に達し, いわば地球そのものが巨大な熱機関である。核とマ ントルの境界 (Core Mantle Boundary, CMB)は, 鉄 合金を主成分とする核とシリケイト成分に富むマン トルとを隔てる固体地球の中で最も大きな化学組成 境界として知られている。核からマントルへと通過 する熱流量は核一マントル相互作用を示す指標の一 つであり, マントル対流, 外核の地磁気の形成・維 持, 内核の成長などの地球深部ダイナミクスを理解 するうえで有用な知見をあたえる $[1]$ 。

$\mathrm{CMB}$ 近傍ではマントルの水平方向の流動が卓越 し，鉛直方向（地球の深さ方向）に大きな温度勾配 が発達した熱境界層が形成されていると考えられて いる。熱境界層の内部では主として熱伝導による伝 熱機構によりエネルギーが輸送される。マントル岩 石の電気的性質は絶縁体であり, 絶縁体中の熱伝導 は一般に結晶格子の振動によるエネルギーの伝達に よって生じる（本稿第 2 章も参照されたい）。この
伝熱機構を格子熱伝導と呼び，これにより輸送され るエネルギー（熱）流速 $(\boldsymbol{q})$ は, 結晶中の温度勾配 $(\nabla T)$ に比例する。その比例係数が格子熱伝導率 $\left(\kappa_{\text {lat }}\right)$ であり, Fourierの法則によってこれらの関係 は $\boldsymbol{q}=-\kappa_{\mathrm{lat}} \nabla T$ と表される。そのため, 下部マント 儿深部の $\kappa_{\text {lat }}$ が分かれば CMB 熱流束 $\left(\boldsymbol{q}_{\mathrm{CMB}}\right)$ を推定 できる。

CMB の直上の抢よそ 100-300 km の下部マント 儿領域では，地震波速度の急峻な増加ならびに横波 の地震波の速度が異なる偏光異方性が観測されてい る[2]。地震波速度のこの異常域は $\mathrm{D}^{\prime \prime}$ 層と呼ばれて いる。 $\mathrm{D}^{\prime \prime}$ 層の主要構成鉱物は $(\mathrm{Mg}, \mathrm{Fe}) \mathrm{SiO}_{3}$ ブリッ ジマナイト $(\mathrm{Brg})$ 扎よびその高圧相のポスト・ペロ

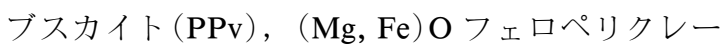
スと考えられている。そのため，これらの鉱物の下 部マントル深部温度 $(T)$. 圧力 $(P)$ 条件 $(T>$ $\sim 2,000 \mathrm{~K}, P>\sim 100 \mathrm{GPa})$ に打ける $\kappa_{\text {lat }}$ 打よび $\mathrm{D}^{\prime \prime}$ 層内の温度勾配がわかれば $\boldsymbol{q}_{\mathrm{CMB}}$ を制約できる。

マントル鉱物の $\kappa_{\text {lat }}$ の高温高圧下における測定を めざした技術開発がこれまでに国内外で積極的に進 められてきた。下部マントルその場条件における $\kappa_{\text {lat }}$ の直接決定は地球深部科学のみならず高温高圧 物性物理学としても挑戦的な課題の一つであるが,

干790-8577 愛媛県松山市文京町 2-5 愛媛大学 地球深部ダイナミクス研究センター

Geodynamics Research Center, Ehime University, 2-5 Bunkyo-cho, Matsuyama, Ehime 790-8577

Electronic address: dekura.haruhiko.mf@ehime-u.ac.jp 
実験研究報告例は皆無である。そのため, 実験研究 に基づく深部マントルの熱伝導率は, 実際の地球深 部条件よりもはるかに低い $P, T$ 条件で測定された $\kappa_{\text {lat }}$ の地球深部条件への外挿に基づいて議論されて いる $[3-15]$ 。

一方，マントル鉱物の $\kappa_{\mathrm{lat}}$ の決定を目指した理論 研究も活発に行われ, この十年間で地球深部マント ルの $\kappa_{\text {lat }}$ の理論的な理解が飛躍的に高まった $[16-$ 25]。その要因は, 近年の計算機の高性能化はもと より，第一原理コンピューターシミュレーション技 術に基づく物性計算法の発展によるところが大きい。 物性シミュレーションに抢ける第一原理（または非 経験的）計算とは, 多数の原子からなる系をその構 成要素である電子・原子核の多体系としてとらえ， 量子力学の原理に基づき系の量子状態ならびに観測 可能な物理量を可能な限り「非経験的に」決定する ことで物性の高精度決定が可能な手法の総称である。

本稿では, 著者が所属する地球深部ダイナミクス 研究センターの鉱物物性理論グループがこれまでに 実施した密度汎関数理論と呼ばれる手法に立脚した 第一原理量子力学計算 [26]による下部マントル鉱物 の $\kappa_{\text {lat }}$ に関して得られた研究成果を中心に紹介する。

\section{2. 格子熱伝導の理論と非調和格子動力学計算法}

前章で述べたと抢り，物質中に温度勾配があると きに格子振動によりエネルギーが伝播することを格 子熱伝導現象とよび，そのエネルギー輸送効率を示 す指標が格子熱伝導率 $\kappa_{\mathrm{lat}}$ であった。本章では, 著 者が用いている手法である非調和格子動力学法によ る $\kappa_{\text {lat }}$ の第一原理計算法の概略を述べる。詳細につ いては[22,27]を参照されたい。

格子振動の基準振動モードを量子化し Bose-Einstein 統計に従う準粒子 “フォノン”を導入するこ とで格子熱伝導による熱輸送の理論的な見通しが良 くなる。格子熱伝導現象が生じている結晶では温度 勾配の存在によって熱平衡状態から外れた状態（非 平衡状態）になっている。そのため，一定の波数べ クトル $\boldsymbol{q}$ と分岐 $\mathrm{s}$ で指定されるフォノン（対応する 固有状態は平面波で表される）のかわりに, 固体内 の位置 $\boldsymbol{r}$ のまわりに狭い広がり $|\boldsymbol{\delta} \boldsymbol{r}|$ をもって局在す るフォノンの “塊” (波束) を考える。このような フォノン波束は, $\boldsymbol{q}$ に分布の極大值, そのまわりに 小さな広がり $|\delta \boldsymbol{q}|$ をもつような重みをつけて固有 振動を重ね合わせて作られる。 $|\delta \boldsymbol{q}|$ は $1 /|\delta \boldsymbol{r}|$ 程度
の大きさをもつ。このフォノン波束に対応するフォ ハンの分布関数 $n_{\mathrm{s}}(\boldsymbol{q}, \boldsymbol{r})$ を導入すると, 熱流束 $(\boldsymbol{Q})$ は

$$
\boldsymbol{Q}=\Sigma_{q, \mathrm{~s}} n_{\mathrm{s}}(\boldsymbol{q}, r) \hbar \omega_{\mathrm{s}}(\boldsymbol{q}) \nabla_{q} \omega_{\mathrm{s}}(\boldsymbol{q})
$$

と書ける。ここでちはディラック定数， $\omega_{\mathrm{s}}(\boldsymbol{q})$ はフ オノン振動数, そして $\nabla_{q} \omega_{\mathrm{s}}(\boldsymbol{q})$ はフォノン波束の群 速度 $\boldsymbol{V}_{\mathrm{s}}(\boldsymbol{q})$ である。一方, 現象論的法則である Fourier の熱伝導則は， $T$ を温度， $x$ を空間座標々 して, $Q_{\alpha}=-\Sigma_{\beta} \kappa_{\alpha \beta} \partial T / \partial x_{\beta}$ と表される（非等方的媒 質の格子熱伝導率はテンソル形式になることに注意 する。 $\kappa_{\alpha \beta}$ は格子熱伝導率テンソルと呼ばれる。 $\alpha$, $\beta$ はデカルト座標系の成分を指定する)。したがっ て，(1)式の右辺を温度勾配 $\nabla \boldsymbol{T}$ について陽に表現 できれば，それに Fourierの法則を要請することで $\kappa_{\alpha \beta}$ のフォノン輸送に基づく微視的な表式が得られ るだろう。そのためには非平衡定常状態に抢けるフ オノン分布関数 $n_{\mathrm{s}}(\boldsymbol{q}, \boldsymbol{r})$ の詳細な知識が必要となる。 非平衡定常状態に打ける $n_{\mathrm{s}}(\boldsymbol{q}, \boldsymbol{r})$ は以下の PeierlsBoltzmann の輸送方程式 [28]

$$
-\boldsymbol{V}_{\mathrm{s}}(\boldsymbol{q}) \cdot \nabla n_{\mathrm{s}}(\boldsymbol{q}, \boldsymbol{r})+\left[\partial n_{\mathrm{s}}(\boldsymbol{q}, \boldsymbol{r}) / \partial t\right]_{\mathrm{scatt}}=0
$$

にしたがう。ここで $t$ は時間を表す。左辺第一項は 温度勾配 $\nabla T$ による $n_{\mathrm{s}}$ の拡散を表し，第二項目は フォノン同士の衝突による分布関数の変化を表して いる。温度勾配が小さいとして $\nabla n_{\mathrm{s}}(\boldsymbol{q}, \boldsymbol{r}) を \nabla T$ の 一次で展開すると $\nabla n_{\mathrm{s}}(\boldsymbol{q}, \boldsymbol{r}) \approx\left(\partial n_{\mathrm{s}}^{0}(\boldsymbol{q}) / \partial T\right) \nabla T$ とか ける。 $n_{\mathrm{s}}^{0}(\boldsymbol{q})$ は熱平衡状態におけるフォノン分布関 数 (Bose-Einstein 分布関数) である。フォノン衝突 項は非線形な積分項を含む複雑な形をしており， これを線形化するため緩和時間近似 (Relaxation Time Approximation, RTA) $\left[\partial n_{\mathrm{s}}(\boldsymbol{q}, \boldsymbol{r}) / \partial t\right]_{\text {scatt }}=$ $-\left(n_{\mathrm{s}}(\boldsymbol{q}, \boldsymbol{r})-n_{\mathrm{s}}^{0}(\boldsymbol{q})\right) / \tau_{\mathrm{s}}^{\mathrm{RTA}}(\boldsymbol{q})$ がしばしば用いられる。 $\tau_{\mathrm{s}}^{\mathrm{RTA}}(\boldsymbol{q})$ は緩和現象を特徵づける緩和時間パラメー タであり, フォノン描像ではフォノン散乱による有 限のフォノン寿命と考えて差し支えない。これらの 近似により輸送方程式の解 $n_{\mathrm{s}}(\boldsymbol{q}, \boldsymbol{r})$ は容易に求まり, それを式(1)に代入し Fourier 則を要請すると, RTA による格子熱伝導率テンソルの表式

$$
\kappa_{\alpha \beta}^{\mathrm{RTA}} \Sigma_{q, \mathrm{~s}} C_{\mathrm{s}}(\boldsymbol{q})\left(\boldsymbol{V}_{\mathrm{s}}(\boldsymbol{q})\right)_{\alpha}\left(V_{\mathrm{s}}(\boldsymbol{q})\right)_{\beta} \tau_{\mathrm{s}}^{\mathrm{RTA}}(\boldsymbol{q})
$$

が得られる。ここで $C_{\mathrm{s}}(\boldsymbol{q})=\partial\left(\hbar \omega_{\mathrm{s}}(\boldsymbol{q}) n_{\mathrm{s}}^{0}(\boldsymbol{q})\right) / \partial T$ はフォノン比熱を表す。RTAに対する補正は Omini らによる繰り返し法などにより可能である 
$[29]$ 。本稿で示す $\kappa_{\text {lat }}$ は, 各結晶の方位がランダム に配向している多結晶体の格子熱伝導率の方位平均 值を示して抢り, 単結晶の線熱伝導率 $\left(\kappa_{\mathrm{aa}}, \kappa_{\mathrm{bb}}\right.$, $\left.\kappa_{\mathrm{cc}}\right)$ の算術平均值 $\left(\kappa_{\mathrm{aa}}+\kappa_{\mathrm{bb}}+\kappa_{\mathrm{cc}}\right) / 3$ 之調和平均値 $3\left(1 / \kappa_{\mathrm{aa}}+1 / \kappa_{\mathrm{bb}}+1 / \kappa_{\mathrm{cc}}\right)^{-1}$ との平均值

$$
\begin{aligned}
\kappa_{\mathrm{lat}}= & {\left[\left(\kappa_{\mathrm{aa}}+\kappa_{\mathrm{bb}}+\kappa_{\mathrm{cc}}\right) / 3+3\left(1 / \kappa_{\mathrm{aa}}+1 / \kappa_{\mathrm{bb}}\right.\right.} \\
& \left.\left.+1 / \kappa_{\mathrm{cc}}\right)-1\right] / 2
\end{aligned}
$$

で与えられる。著者らの $\mathrm{MgO} の \kappa_{\text {lat }}$ に対する計算 では, 線形化された Peierls-Boltzmann 方程式の完 全解は RTA に基づく解に比べて抢よそ 30\%大きく なった $[22]$ 。この原因はフォノンーフォノン散乱の 性質に起因している。なお, Brg や PPvでは RTA への補正は数パーセント程度である $[25]$ 。 RTAに よる解の䛊差について興味のある読者は $[22,30] を$ 参照されたい。

て は格子系の Hamiltonian においてフォノン一フ オノン相互作用を摂動項にとり Fermi の黄金律を 利用してフォノン状態の遷移確率から評価が可能で ある。フォノン一フォノン相互作用の次数の増加に 応じてての理論的な表式はより複雑となり計算量も それに伴い増加する。フォノンの多体相互作用のよ り系統的な取り扱いとしては, 相互作用するフォノ ン系の Green 関数を無摂動フォノン Green 関数 （フォノン場の固有状態から構築される）により摂 動展開し多体フォノン吸収・放出過程を扱う方法が ある。この場合, フォノン一フォノン散乱による遷 移確率とフォノンエネルギーの変化は, フォノン Green 関数の自己エネルギーの虚部と実部にそれぞ れが関係付けられる。興味がある読者は $[31,32] を$ 参考にしてほしい。

フォノン振動数 $\omega_{\mathrm{s}}(\boldsymbol{q})$, 群速度 $\boldsymbol{V}_{\mathrm{s}}(\boldsymbol{q})$, 比熱 $C_{\mathrm{s}}(\boldsymbol{q})$ はフォノン分散関係から計算できる。分散関 係は, 原子間に働く力の調和項を考慮し調和動力学 行列を構築し, それの固有值問題を解くことで得ら れる。これは格子動力学法と呼ばれる。一方で, フ オノン寿命 $\tau$ の決定には上述の調和力にくわえて非 調和力を考量し非調和動力学テンソルを計算する必 要がある。原子間に働く復元力のうち非調和項も取 り扱うため, 非調和格子動力学法と呼ばれる。密度 汎関数理論に基づく非調和力の第一原理計算法では 実空間差分法が主に用いられている。この方法では, 平衡位置にある原子を変位させることで系の断熱ポ テンシャルエネルギー曲面を構築し, 平衡位置（極 小值）周りのポテンシャルの高次導関数を数值的に
求め調和・非調和力を決定する。手法の計算機上の 実装は困難ではなく，必要に応じて高次の非調和テ ンソルの決定が可能だが, 非調和動力学定数のシミ ュレーションセルサイズ依存性や数值微分のための グリッド間隔の調整など, 動力学テンソルしたがっ てフォノン寿命 $\tau$ の高精度決定のためには計算条件 の注意深い選定が必要となる。実空間法以外にも, 密度汎関数摂動論 (Density Functional Perturbation Theory, DFPT) に基づく第一原理非調和格子動力学 法などが知られているが，高次非調和相互作用の系 統的な計算法の実装が容易ではないため研究適用例 は極めて限られている $[19,33]$ 。近年, 三次の非調 和動力学テンソルの第一原理計算により得られた $\kappa_{\text {lat }}$ の研究がシリコンやダイヤモンドなど比較的単 純な結晶構造をもつ物質を中心に物質・材料科学分 野で多数報告されている $[34]$ 。計算された $\kappa_{\mathrm{lat}}$ は実 験值を非常によく再現しており，それらの物質のフ オノン伝導による熱輸送機構の理解を大いに進展さ せた。しかし，当該手法を $\mathrm{Brg}$ や PPv など複雑な 結晶構造をもつ地球深部物質へと適用した研究事例 は極めて限られており, 著者らの研究グループを含 めごくわずかである。次章以降では，下部マントル の主要構成鉱物である $\mathrm{MgO}, \mathrm{Brg}, \mathrm{PPv}$ の $\kappa_{\mathrm{lat}}$ の著 者らによる第一原理計算の最新の結果を紹介する。

\section{3. 下部マントル鉱物への適用}

\subsection{MgO の格子熱伝導率}

Fig. $1 \mathrm{a}$ に $\mathrm{MgO}$ の高温高圧下に拈ける $\kappa_{\text {lat }}$ を示す。 およそ $40 \mathrm{GPa}$ までは著者らによる第一原理非調和 格子動力学法を用いた計算值 $[22]$ は先行実験・理論 研究と打打むね調和的である $[16-18,35]$ (Fig. 1a)。加圧にともない, 先行理論研究による計算值 は著者らの結果から有意にずれている。CMB 条件 $(P \sim 136 \mathrm{GPa}, T \sim 4,000 \mathrm{~K})$ において Tang and Dong [16]の同位体効果を考慮した RTA による計算值は 著者らが決定した $\kappa_{\text {lat }}$ と調和的だが，高温高圧条件 に抢ける $\kappa_{\text {lat }}$ の圧力依存性は全く異なっている。 Tang and Dong[16]はフォノン寿命を決定するため の非調和力定数を最近接原子についてのみ考慮して おり，より長距離間の非調和相互作用を計算に取り 入れていない。そのため, 彼らの計算ではフォノン 寿命したがって $\kappa_{\text {lat }}$ が十分に収束して抢らず，圧力 依存性に関する上述の相違が生じている可能性が Dekura and Tsuchiya[22]により指摘されている。 

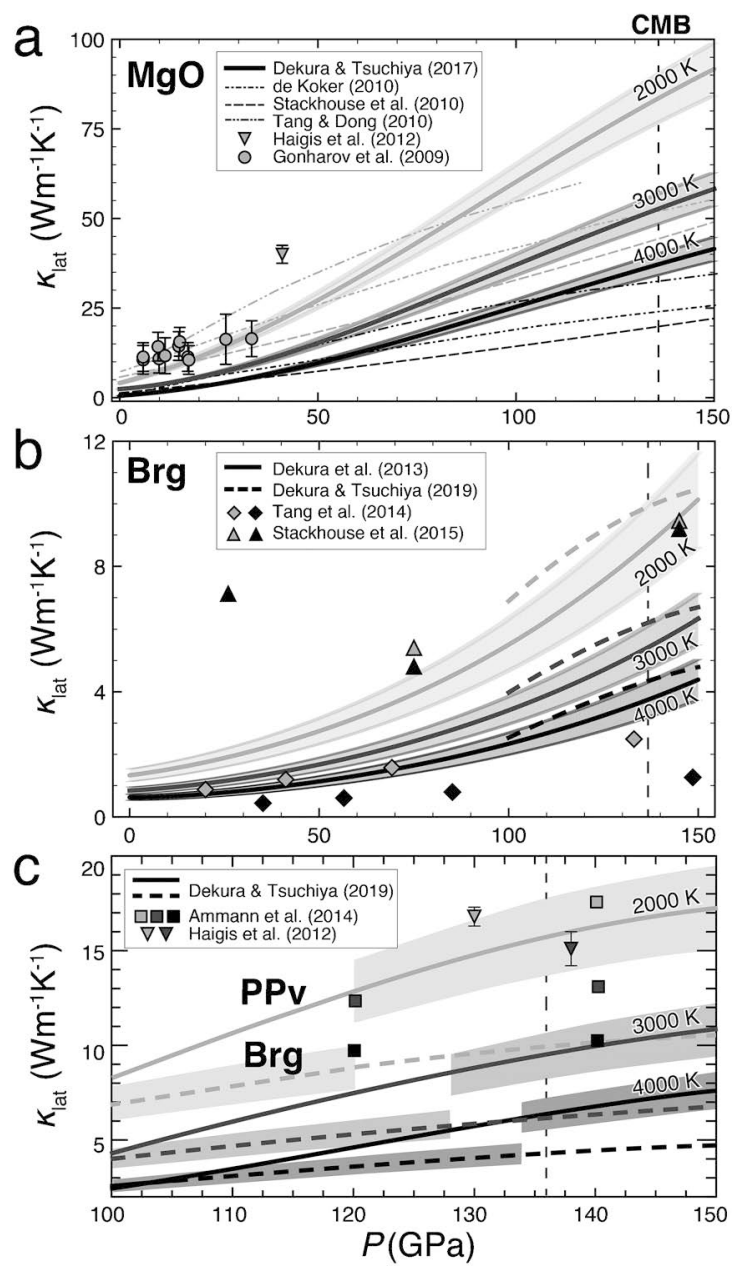

Fig. 1. Lattice thermal conductivity $\left(\kappa_{\text {lat }}\right)$ of (a) $\mathrm{MgO}$, (b) $\mathrm{Brg}$, and (c) PPv for isotropic aggregate as a function of pressure $(P)$ at 2,000 (light gray), 3,000 (gray), and $4,000 \mathrm{~K}$ (black) with computational uncertainties (shaded bands) (modified after Ref.[26]). The experimental values for $\mathrm{MgO}$ at $2,000 \mathrm{~K}$ (data from Goncharov et al. [6]) are also indicated (light gray circles), while no experimental data are available for Brg and $\mathrm{PPv}$ in the corresponding $P, T$ range so far.

また, 分子動力学 (Molecular Dynamics, MD) 法 に基づく先行研究值と著者らによる計算結果との間 にみられる差は, 熱輸送に寄与するフォノンが十分 にサンプリングされていない[17]，不十分な MD シミュレーション時間 $[18]$ などに起因しているのか もしれない。なお，経験的な原子間ポテンシャルを 用いた古典 MD 法（非第一原理計算）による計算 值 [36]は，これらの第一原理研究報告值から大きく かけ離れている。 $\kappa_{\text {lat }}$ を決定するうえで必要となる
原子間力の非調和性の記述には原子間ポテンシャル の二次以上の高次微分が必要であり, ポテンシャル の一次微分の情報から決定される比熱などの調和熱 物性值よりも数值誤差が大きくなる。これが古典 MD 法による研究報告值と第一原理計算值との大き な差が生じている原因かもしれない。

\section{$3.2 \mathrm{MgSiO}_{3}$ ブリッジマナイト $(\mathrm{Brg})$ の格子熱伝導率}

$\mathrm{Brg}$ の結晶構造は基本単位格子に 20 原子を含み, わずか 2 原子しか含まない $\mathrm{MgO}$ の結晶構造と比べ ると複雑である。一般的に， $\kappa_{\text {lat }}$ の決定のために必 要となる非調和格子動力学行列のサイズは, 計算で 考慮する原子数の三乗に比例する。それを反映して, $\operatorname{Brg}$ の $\kappa_{\text {lat }}$ の決定のために必要となる計算コストは $\mathrm{MgO}$ と比べて高くなる。古典 MD 法による研究 [36]の後に, 著者らが報告した RTA 抢よびフォノ ンーフォノン散乱頻度に Klemens 近似[27]を用い た DFPT に基づく第一原理非調和格子動力学法に よる研究 $[19]$ を皮切りとして, 第一原理計算值が相 次いで報告された $[20,21,23,25]$ 。Fig. 1bに，これ までに報告されている $\mathrm{Brg}$ の下部マントル条件に 打ける $\kappa_{\text {lat }}$ を示す。Tang ら[20]はRTAを用いた第 一原理非調和格子動力学に基づいた計算を行い, 著 者らの研究を含む第一原理非調和格子動力学計算値 $[19,23,25]$ ならびに第一原理 MD 計算值 $[21]$ より 非常に小さな圧力依存性を報告した。比熱や熱状態 方程式に関しては研究間で概ね良く一致するため, この圧力依存性についての不一致の原因は Tang ら [20]で用いられた非調和相互作用計算のための計算 セットアップなどに起因していると考えられる。

$\mathrm{CMB}$ 条件 $(P \sim 136 \mathrm{GPa}, T \sim 4,000 \mathrm{~K})$ に打ける $\kappa_{\text {lat }}$ の值は研究間で大きく異なっている。Klemens 近似㧍よびRTA を用いたDFPT 計算值 $[19]$ と, 線 形化された Peierls-Boltzmann 方程式 (2 章 式 (2)) の完全解 $[23,25]$ では， $\kappa_{\text {lat }}$ が〜 $4-5 \mathrm{Wm}^{-1} \mathrm{~K}^{-1}$ と見 積もられている。一方, Tang らによるRTAにも とづく非調和格子動力学計算値は, 先述した小さな 圧力依存性のためかなり小さい值 $1 \mathrm{Wm}^{-1} \mathrm{~K}^{-1}$ と なっている $[20]$ 。また， Stackhouse らによる第一 原理非平衡 MDによる研究では最も大きな值 $\left(\sim 9 \mathrm{Wm}^{-1} \mathrm{~K}^{-1}\right)$ が報告されている[21]。CMB 条件 における $\kappa_{\text {lat }}$ の值の違いをもたらす原因は当該 MD 計算でみられた $\kappa_{\text {lat }}$ の弱い温度依存性に起因してい る[21] (Fig. 1b)。彼らはこれを“飽和効果” と呼 び，その原因は加温に伴いフォノンの平均自由行程 
$\left(L_{\mathrm{ph}}\right)$ が原子間距離程度にあで小さくなるためであ ると推測した。これは以下の考えに基づいていると 思われる。 $L_{\mathrm{ph}}$ が加温にともない原子間距離のオー ダーまで短くなると, Peierls-Boltzmann 方程式を 構築するうえで仮定したフォノン波束が定義できな くなる。その場合, 2 章で記述した PeierlsBoltzmann によるフォノン伝導の理論が破綻する可 能性がある[37]。このことは古くから指摘されてお り， $L_{\mathrm{ph}}$ はある最小值よりも小さくなれないことで 加温に伴い $\kappa_{\mathrm{lat}}$ の温度依存性が小さくなり得る $[38]$ 。

Stackhouse ら[21]によるMD 手法は, 非調和格 子動力学法とは異なり, フォノン寿命 $\tau$ およびフォ ノン群速度 $V$ を直接決定できず， $L_{\mathrm{ph}} \sim \tau V$ を定量 的に見積もることができない。そこで著者らは Stackhouse ら[21]の主張を検証すべく〜 $130 \mathrm{GPa}$, $4,000 \mathrm{~K}$ に抢ける $\mathrm{Brg}$ の三次までの非調和性を考慮 した $L_{\mathrm{ph}}$ の熱平均值を直接評価した。その結果, 同 $P, T$ 条件において $L_{\mathrm{ph}}$ が〜 $70 \AA$ と見積もられたが [25], この值は $\mathrm{Brg}$ の最近接原子間距離 $(\mathrm{Si}-\mathrm{O}$, $\sim 1.7 \AA$ A) よりも十分に大きいため, Stackhouse らに よる “飽和効果” は生じないということになる。な お, PPvについても Brgのときと同様の結論が得 られた $\left(L_{\mathrm{ph}} \sim 80 \AA\right)[25]$ 。

一般に，高温になるにつれて三次以上の非調和性 があらわれフォノンーフォノン散乱強度はより大き くなることでフォノン寿命はより小さくなり，それ に伴い $\kappa_{\text {lat }}$ は三次の非調和性のみを考慮した場合よ りもすみやかに減少することが理論的に期待される [39]。それにより $\mathrm{Brg}$ (および $\mathrm{PPv}, \mathrm{MgO}$ )の $L_{\mathrm{ph}}$ は 三次までの非調和性までを考慮して見積もった上述 の值よりも小さくなるだろうが，それが原子間距離 のオーダーまで短くなり熱伝導率の “飽和” が生じ るには, 四次以上の非調和性が三次のそれよりも強 い必要があるだろう。一般に非調和相互作用は高次 になるにつれて小さくなるため, この要請は直感的 には非物理的なものと思われる。フォノン寿命・群 速度抢よび $\kappa_{\mathrm{lat}}$ の温度依存性に対する高次のフォノ ン一フォノン散乱の影響に関する第一原理研究は,

現在のところ Si などの単純な構造をもつ物質に限 られ発展途上の段階にある $[39]$ 。超高温下に打ける Peierls-Boltzmannのフォノン輸送理論の正当性の 検証をも踏をえた今後の理論研究の展開が期待され る。

\section{$3.3 \mathrm{MgSiO}_{3}$ ポスト・ペロブスカイト (PPv)の格子 熱伝導率}

$\mathrm{MgO}$ および $\mathrm{Brg}$ とは異なり， PPvの $\kappa_{\text {lat }}$ の第一 原理計算は著者らによる研究の久報告されている。 第一原理非調和格子動力学法により決定した, PPv の下部マントル深部条件に拈ける $\kappa_{\text {lat }}$ を Fig. 1c に 示す $[25]$ 。 PPvの $\kappa_{\text {lat }}$ が $\mathrm{Brg}$ より $50 \%$ 以上大きく なることがわかった。この増加の原因は, $\mathrm{Brg}$ から $\mathrm{PPv}$ への相転移に伴いフォノン群速度㧍よびフォ ハン寿命がともに増加するためである。前者の増加 は相転移による密度増加に起因し, 後者はフォノン 一フォノン散乱のチャネル数の減少に伴う非調和相 互作用強度の低下によるものである。ここで得られ た熱伝導率への相転移の効果は，4章で下部マント ル最深部の熱伝導率のモデリングの際に考慮される。

経験的ポテンシャルを用いた MD 計算值 $[36,40]$ は著者らによる第一原理計算值と $T \sim 2,000 \mathrm{~K}$ で調 和的である。しかし，マントル最深部温度 $(T$ ～ $4,000 \mathrm{~K})$ 条件に近づくにつれて顕著な差が現れてい る。3.1 節の $\mathrm{MgO}$ の古典 $\mathrm{MD}$ による研究例で述べ たとおり，一般に格子熱伝導率は原子間ポテンシャ ルの関数形に極めて敏感である。そのため，モデル ポテンシャルを用いたこれらの MD 研究では非調 和相互作用を精度良く決定できていない可能性があ り，上述の第一原理計算との有意なずれが生じてい るのかもしれない。

\section{CMB 熱流束}

\section{1 最深部マントルの熱伝導率}

1 章で述べたとおり, CMB 熱流束 $\left(\boldsymbol{q}_{\mathrm{CMB}}\right)$ は核と マントルの熱的結合の強さを表す指標の一つであり, $q_{\mathrm{CMB}}$ は Fourier の法則 $\left(\boldsymbol{q}_{\mathrm{CMB}}=-\kappa_{\text {lat }} \nabla T\right)$ から計算で きる。本節では 3 章で紹介した下部マントルの主要 構成鉱物と考えられる $\mathrm{MgO}, \mathrm{Br}$ および $\mathrm{PPv}$ の $\kappa_{\text {lat }}$ の第一原理計算值 $[22,25]$ を用いた $q_{\mathrm{CMB}}$ の見積りを 紹介する。著者らは, 下部マントル最深部の熱伝導 率をモデル化するためにパイロライト的な下部マン トルの化学組成の多結晶体 $\left(\mathrm{MgSiO}_{3} \mathrm{Brg}\right.$ または $\mathrm{PPv}$ と $\mathrm{MgO}$ の体積比が $8: 2)$ を想定し, それらの 鉱物組成平均值を Hashin-Shtrikman 平均で求めた [25］。このようにして求めた CMB 条件に抢ける実 効的熱伝導率 $\left(\kappa_{\text {eff }}\right)$ は, $\mathrm{PPv}+\mathrm{MgO}$ 多結晶体で $\kappa_{\text {eff }}$ $\sim 12 \mathrm{Wm}^{-1} \mathrm{~K}^{-1}, \mathrm{Brg}+\mathrm{MgO}$ 多結晶体では $\kappa_{\mathrm{eff}} \sim$ $8.5 \mathrm{Wm}^{-1} \mathrm{~K}^{-1}$ となる。 $\mathrm{PPv}+\mathrm{MgO}$ 多結晶体の $\kappa_{\mathrm{eff}}$ 
が $\mathrm{Brg}+\mathrm{MgO}$ 多結晶体のそれよりも〜 40\%ほど大 きくなる要因は 3.3 節で述べた PPv 相転移に伴う $\kappa_{\text {lat }}$ の増加によるものである $[25]$ 。相転移による $\kappa_{\mathrm{eff}}$ のこの急峻な増加により, PPv 相転移境界が鉱 物相境界であるのみならず熱伝導特性に関しても境 界となっていることを示している。

$\boldsymbol{q}_{\mathrm{CMB}}$ の計算のためには $\kappa_{\mathrm{eff}}$ にくわえて下部マン トル深部の温度構造の情報が必要である。著者らは D"不連続面が Brg-PPv 相転移に起因して形成され ると仮定し，第一原理計算によって得られた比熱， 密度, そして $\kappa_{\text {eff }}$ を用いた一次元熱伝導程式を設定 し，それを解くことで深部マントルの温度構造をモ デル化した (Fig. 2)。D”層の高温 (hot) 域と低温 (cold) 域の温度勾配はそれぞれ $\nabla T \sim 1.4 \mathrm{~K} \mathrm{~km}^{-1}$ お よび $\nabla T \sim 18 \mathrm{~K} \mathrm{~km}^{-1}$ と求まり，それらに対応する $q_{\mathrm{CMB}}$ がそれぞれ， $q_{\mathrm{hot}}=23.5 \mathrm{mWm}^{-2}$ と $q_{\text {cold }}=$ $204.8 \mathrm{mWm}^{-2}$ と見積もられた。この結果から, $\mathrm{D}^{\prime \prime}$ 層の温度勾配 $\nabla T$ の不均質性に加えて, PPv 相転 移に伴う $\kappa_{\mathrm{eff}}$ の増加により, $\boldsymbol{q}_{\mathrm{CMB}}$ の水平方向の不 近質性がより強まることが定量的に理解される $[25]$ 。 $q_{\mathrm{CMB}}$ の地域依存性は地球磁場の強度变化や内核成 長へ影響を及ぼすと考えられている $[41]$ 。本研究で 得られた第一原理計算値に基づく $\boldsymbol{q}_{\mathrm{CMB}}$ の水平不均 質性を考慮した核の対流・磁場シミュレーションの 実施により，核ダイナミクスのさらなる理解の促進 が期待される。

$\mathrm{D}^{\prime \prime}$ 層の $\mathrm{CMB}$ 熱流束の平均值 $\left(q_{\mathrm{av}}=\left(q_{\mathrm{cold}}+q_{\mathrm{hot}}\right) / 2\right.$

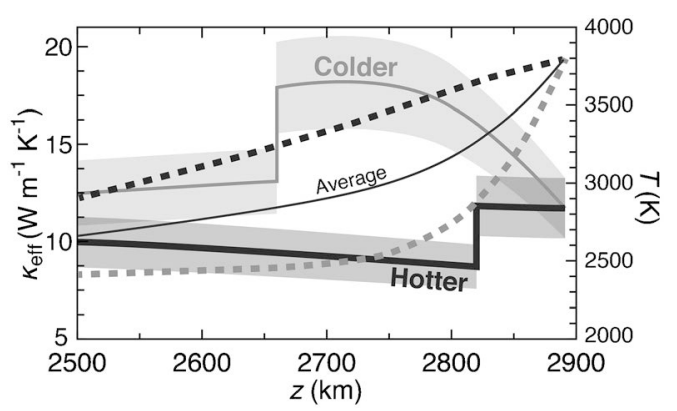

Fig. 2. Effective lattice thermal conductivity $\left(\kappa_{\text {eff }}\right)$ of the lowermost mantle (solid lines) as a function of depth $(z)$ obtained by the composite average of $\mathrm{MgSiO}_{3} \mathrm{Brg}$ or PPv (80 vol\%) and $\mathrm{MgO}$ (20 vol\%) with computational uncertainties (shaded bands) in Earth's lowermost mantle along the model temperature profiles of the hotter and colder regions (dashed lines, right-hand axis) (modified after Ref.[25]). The average temperature profile is also provided (thin solid line).
〜114 $\left.\mathrm{mWm}^{-2}\right)$ を用いると, CMB 熱流量の総量が $\sim 17 \mathrm{TW}$ と見積もられる $[25]$ 。この值は, 地球核 の熱伝導についての最近の第一原理計算 $[42,43]$ 扮 よび高圧実験 [44]によって推定されている CMB 熱 流量の推定值 $(\sim 15 \mathrm{TW})$ と調和的である。この良い 一致は核の熱伝導率研究によって推定された外核上 部の熱的安定成層の形成の可能性 [45]や若い内核年 齢（<〜10 億年）[46]を，マントル深部の熱伝導 率研究からも支持することになる。しかし，4.3 節 で述べるように，不純物（とくに，鉄）の混入によ るフォノン一不純物散乱により下部マントル鉱物の $\kappa_{\text {lat }}$ が低下することが室温実験・理論研究で報告さ れて抢り，マントル側から見積もられた上述の CMB 熱流量は過大評価されている可能性がある。

\section{$4.2 \operatorname{PPv}$ の格子熱伝導率の異方性による CMB 熱 流束への影響}

D"層では対流の境界層のため岩石が大きく変形 して抢り，顕著な地震波速度異方性が検出されてい る。そこでは水平方向に伝播する横波の地震波速度 の大きさ $\left(V_{\mathrm{SH}}\right)$ が垂直方向に伝播するそれ $\left(V_{\mathrm{SV}}\right)$ よ りも大きい[2]。マントル内部では, 高応力場で岩 石が転位クリープで塑性変形していると考えられて いる。塑性変形に伴い PPv 結晶の方位がある向き に揃う結晶方位選択配列 (Crystal Preferred Orientation, CPO)の発達が，最下部マントルで観測される 速度異方性が生じる機構の一つとして提案されてい る[47-49]。 $V_{\mathrm{SH}}$ 抢よび $V_{\mathrm{SV}}$ は弾性定数の情報を基 にして決定できる。PPvの弾性定数の第一原理計 算によれば，上述の地震波速度異方性を PPvの $\mathrm{CPO}$ 形成に基づいて説明するには, PPv 結晶の $c$ 軸方向が CMB に対して垂直な方向に選択配向する 必要がある $[48,49]$ 。そこで著者らは $\boldsymbol{q}_{\mathrm{CMB}}$ に対する PPv 結晶の選択配向による影響を調べるため, PPv の結晶軸 $(a, b, c)$ 方向の熱伝導率（線熱伝導率 $\kappa_{\mathrm{a}}$, $\left.\kappa_{\mathrm{b}}, \kappa_{\mathrm{c}}\right)$ を調べ，それらと選択配向していない場合 （本稿 2 章 式 $(4)$ を参照）の熱伝導率 $\left(\kappa_{\text {lat }}\right)$ を比較し た。その結果, $c$ 軸方向に選択配向した場合の線熱 伝導率 $\kappa_{\mathrm{c}}$ と, 結晶がランダムに配向している場合 の熱伝導率 $\kappa_{\text {lat }}$ との差はわずかであり， $q_{\mathrm{CMB}} へ の$ $\mathrm{PPv}$ 結晶の選択配向による影響は小さいことを明 らかにした(Fig. 3)。詳細については Dekura and Tsuchiya[25]を参照されたい。 


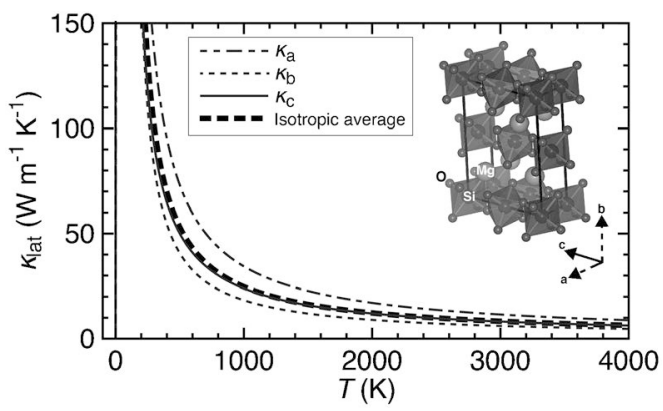

Fig. 3. Crystallographic axis dependence of lattice thermal conductivity of PPv as a function of temperature $(T)$ at a static pressure of $100 \mathrm{GPa}$ (modified after Ref.[25]). The conductivity for each direction is plotted along the orthorhombic $a\left(\kappa_{\mathrm{a}}\right), b\left(\kappa_{\mathrm{b}}\right)$, and $c$ axes $\left(\kappa_{\mathrm{c}}\right)$. The isotropic average for the polycrystalline aggregate $\left(\kappa_{\text {lat }}\right.$, see section 2 ) is also provided (bold dashed line). The crystal structure is depicted in the inset.

\section{3 不純物元素の固溶効果}

下部マントル鉱物は鉄とアルミニウムが固溶する ことが知られている。そのため，より現実的な深部 マントルの $\kappa_{\text {lat }}$ を決定するためには, これらの不純 物の固溶による $\kappa_{\mathrm{lat}}$ への影響を考慮する必要がある。 $\mathrm{Brg}$ 抢よび $\mathrm{MgO}$ の $\kappa_{\mathrm{lat}}$ の鉄固溶にともなう減少が 最近の高圧室温実験・理論研究で報告されており [7,9,11-15,24], 下部マントル条件に打ける鉄固溶 効果の解明が期待されている。くわえて, $\mathrm{Mg}-\mathrm{PPv}$ の $\kappa_{\text {lat }} へ$ の不純物固溶効果についての研究報告例は 皆無であり, 最深部マントルの熱輸送特性の制約を めざした今後のさらなる理論・実験研究の発展が望 まれる。本稿で紹介した第一原理非調和格子動力学 法は不純物が固溶した系への拡張が可能である。現 在, 著者らは下部マントル鉱物の深部マントル条件 に抢ける $\kappa_{\mathrm{lat}}$ への鉄固溶効果を調べるため, 内部無 撞着 LSDA $+U$ 法 $[53]$ と呼ばれる手法を組み合わ せた第一原理非調和格子動力学シミュレーションを 実施している。

\section{5. おわりに}

2010 年に学位を取得して後, 愛媛大学地球深部 ダイナミクス研究センター・土屋卓久教授と着手し た地球深部構成鉱物の格子熱伝導率の研究は, 三次 までの非調和性を考慮した近似で遷移金属元素を含 まないバルク物質を対象とするのなら, 現在では
ルーティーンで決定できる段階に到達した。しかし， 以下の通り地球惑星深部に抢ける熱伝導率の高精度 決定のためには，明らかにすべき課題が残っている。 4.3 節でも述べた鉄固溶効果の検証, 結晶粒界の存 在によるフォノン散乱の影響, 非常に高温になると 生じ得る四次以上の非調和性の熱伝導率への影響な どである。また，地球史を通じて形成され地球深部 に化学的不均質を引き抢こしていると考えられてい る始原物質の熱伝導率と CMB 熱輸送特性への影響 についても今後の研究の進展が望まれる。さらに, 本稿では割愛したが, 最下部マントルでは光子（フ オトン）輻射による熱伝達（放射熱伝達）による CMB 熱輸送特性への寄与も指摘されている。放射 熱伝導率は加温とともに上昇するため, 深部マント ルの熱輸送特性をさらに精密化するうえで考慮すべ きであるが，報告された放射熱伝導率值は実験間で $\sim 0.5-\sim 10 \mathrm{Wm}^{-1} \mathrm{~K}^{-1}$ とばらついて抢り不確定性 が大きい [50-52]。光輻射による熱輸送を規定する ものは, フォトンの吸収・放射過程と輻射スペクト ルである。これらは物質の電子構造を強く反映する ため, 高温高圧下に抢ける光学特性の第一原理研究 も今後のさらなる実験研究にくわえて必要となるで あろう。これらの理論・実験研究の進展により得ら れる知見を統合することで, 地球深部ダイナミクス の理解が飛躍的に促進されるだろう。

\section{謝 辞}

固体地球科学の研究者なら誰もが知っている PREM す知らなかった著者が，愛媛大学で博士 研究員になりたての頃から十年間にわたりお世話に なっている共同研究者の愛媛大学地球深部ダイナミ クス研究センター・土屋 卓久 教授ならびに土屋 旬 准教授の抢二方には筆舌に尽くしがたい謝意を 表します。本稿の執筆の機会を与えてくださった東 京工業大学・太田 健二 准教授にもあわせて深く謝 意を表します。同氏は研究テーマも近いことから， これまでに幾度となく研究上の議論をしていただき ました。また, 佐津川 貴子 博士ならびに愛媛大学 地球深部ダイナミクス研究センター・西 真之 准教 授の両名には本稿を執筆するうえで建設的なコメン トを多くいただきました。ここに感謝の意を表しま す。本研究は科学研究費補助金（新学術領域研究 15H05834）の助成を受け実施したものです。 


\section{参考文献}

[1] T. Lay, J. Hernlund, B.A. Buffett: Nat. Geosci., 1, 25 (2008).

[2] T. Lay, Q. Williams, E.J. Garnero: Nature, 392, 461 (1998).

[3] M. Osako, E. Ito: Geophys. Res. Lett., 18, 239 (1991).

[4] T. Katsura: Phys. Earth Planet. Inter., 101, 73 (1997).

[5] A.M. Hofmeister: Science, 283, 1699 (1999).

[6] A.F. Goncharov, P. Beck, V.V. Struzhkin, B.D. Haugen, S.D. Jacobsen: Phys. Earth Planet. Inter., 174, 24 (2009).

[7] G.M. Manthilake, N. de Koker, D.J. Frost, C.A. McCammon: Proc. Natl. Acad. Sci. USA, 108, 17901 (2011).

[8] K. Ohta, T. Yagi, N. Taketoshi, K. Hirose, T. Komabayashi, T. Baba, Y. Ohishi, J. Hernlund: Earth Planet. Sci. Lett., 349-350 (C), 109 (2012).

[9] A.F. Goncharov, S.S. Lobanov, X. Tan, G.T. Hohensee, D.G. Cahill, J.F. Lin, S.M. Thomas, T. Okuchi, N. Tomioka: Phys. Earth Planet. Inter., 247 (C), 11 (2014).

[10] S. Imada, K. Ohta, T. Yagi, K. Hirose, H. Yoshida, H. Nagahara: Geophys. Res. Lett., 41, 4542 (2014).

[11] K. Ohta, T. Yagi, K. Hirose, Y. Ohishi: Earth Planet. Sci. Lett., 465, 29 (2017).

[12] W.P. Hsieh, F. Deschamps, T. Okuchi, J.F. Lin: J. Geophys. Res. Solid Earth, 122, 4900 (2017).

[13] Y. Okuda, K. Ohta, T. Yagi, R. Sinmyo, T. Wakamatsu, K. Hirose, Y. Ohishi: Earth Planet. Sci. Lett., 474, 25 (2017).

[14] W.P. Hsieh, F. Deschamps, T. Okuchi, J.F. Lin: Proc. Natl. Acad. Sci. USA, 115(16), 4099 (2018).

[15] Y. Okuda, K. Ohta, R. Sinmyo, K. Hirose, T. Yagi, Y. Ohishi: Earth Planet. Sci. Lett., 520, 15 (2019).

[16] X. Tang, J. Dong: Proc. Natl. Acad. Sci. USA 107, 4539 (2010).

[17] N. de Koker: Earth Planet. Sci. Lett., 292, 392 (2010).

[18] S. Stackhouse, L. Stixrude, B.B. Karki: Phys. Rev. Lett., 104, 208501 (2010).

[19] H. Dekura, T. Tsuchiya, J. Tsuchiya: Phys. Rev. Lett., 110(2), 025904 (2013).

[20] X. Tang, M.C. Ntam, J. Dong, E.S.G. Rainey, A. Kavner: Geophys. Res. Lett., 41, 2746 (2014).

[21] S. Stackhouse, L. Stixrude, B.B. Karki: Earth Planet. Sci. Lett., 427, 11 (2015).

[22] H. Dekura, T. Tsuchiya: Phys. Rev. B, 95,
184303 (2017).

[23] N. Ghaderi, D.B. Zhang, H. Zhang, J. Xian, R.M. Wentzcovitch, T. Sun: Sci. Rep., 7, 5417 (2017).

[24] Y. Song, K. He, J. Sun, C. Ma, M. Wan, Q. Qang, Q. Chen: Sci. Rep., 9, 4172, (2019).

[25] H. Dekura, T. Tsuchiya: Geophys. Res. Lett., 46, 12919 (2019).

[26] T. Tsuchiya J. Tsuchiya H. Dekura, S. Ritterbex: Annu. Rev. Earth Planet., 48 (2020).

[27] J.M. Ziman: Electrons and Phonons (Oxford University Press, London, 1960).

[28] R.E. Peierls: Ann. der Physik, 3, 1055 (1929).

[29] M. Omini, A. Sparavigna: Phys. Rev. B, 53, 9064 (1996).

[30] A. Ward, D.A. Broido, D.A. Stewart, G. Deinzer: Phys. Rev. B, 80, 125203 (2009).

[31] G.K. Horton, A.A. Maradudin, eds.: Dynamical Properties of Solids: Crystalline solids, fundamentals (North-Holland, Amsterdam, 1974). [32] A.A. Maradudin, A.E. Fein, G.H. Vineyard: Phys. Stat. Solidi B, 2, 1479 (1962).

[33] L. Paulatto, I. Errea, M. Calandra, F. Mauri: Phys. Rev. B, 91, 054304 (2015).

[34] L. Lindsay, D.A. Broido, T.L. Reinecke: Phys. Rev. B, 87, 165201 (2013).

[35] D.A. Dalton, W. Hsieh, G.T. Bodensee, D.G. Cahill, A.F. Gorchakov: Sci. Rep., 3, 2400 (2013).

[36] V. Haigis, M. Salanne, S. Jahn: Earth Planet.

Sci. Lett., 355-356 (C), 102 (2012).

[37] T. Sun, P.B. Allen: Phys. Rev. B, 82, 224305 (2010).

[38] M.C. Roufosse, P.G. Klemens: J. Geophys. Res., 79, 703 (1974).

[39] T. Feng, L. Lindsay, X. Ruan: Phys. Rev. B, 96, 161201(R) (2017).

[40] M.W. Ammann, A.M. Walker, S. Stackhouse, J. Wookey, A.M. Forte, J.P. Brodholt, D.P. Dobson: Earth Planet. Sci. Lett., 390 $($ C $), 175$ (2014).

[41] P. Olson: Geochem. Geophys. Geosyst., 17, 1935 (2016).

[42] N. de Koker, G. Steinle-Neumann, V. Vlcek: Proc. Natl. Acad. Sci. USA, 109, 4070 (2012).

[43] M. Pozzo, C. Davies, D. Gubbins, D. Alfe: Nature, 485, 335 (2012).

[44] K. Ohta, Y. Kuwayama, K. Hirose, K. Shimizu, Y. Ohishi: Nature, 534, 95 (2016).

[45] G. Helffrich, S. Kaneshima: Nature, 468, 807 (2010).

[46] H. Gomi, K. Ohta, K. Hirose, K.S. Labrosse, R. Caracas: Phys. Earth Planet. Inter., 224, 88 (2013).

[47] A.K. McNamara, S.-I. Karato, P.E. van Keken: Earth Planet. Sci. Lett., 191, 85 (2001). 
[48] T. Tsuchiya, J. Tsuchiya, K. Umemoto, R.M. Wentzcovitch: Geophys. Res. Lett., 31, L14603 (2004).

[49] R.M. Wentzcovitch, T. Tsuchiya, J. Tsuchiya: Proc. Natl. Acad. Sci. USA, 103, 543 (2006).

[50] H. Keppler, L.S. Dubrovinsky, O. Narygina, I. Kantor: Science, 322, 1529 (2008).

[51] A.F. Goncharov, B.D. Haugen, V.V. Struzhkin, P. Beck, S.D. Jacobsen: Nature, 456, 231
(2008).

[52] S.S. Lobanov, N. Holtgrewe, J.F. Lin, A.F. Goncharov: Earth Planet. Sci. Lett., 479, 43 (2017). [53] X. Wang, T. Tsuchiya, A. Hase: Nat. Geosci., 8, $556(2015)$.

[2020 年 3 月 8 日受付， 2020 年 5 月 27 日受理] C) 2020 日本高圧力学会 